This is an author produced version of a paper published in International journal of Biological Macromolecules. This paper has been peerreviewed but may not include the final publisher proof-corrections or pagination.

Citation for the published paper:

S.-W. Cho, M. Gällstedt, E. Johansson and M. S. Hedenqvist (2011) Injection-molded nanocomposites and materials based on wheat gluten.

International journal of Biological Macromolecules. Volume: 48 Number: 1, pp 146-152.

http://dx.doi.org/doi:10.1016/j.ijbiomac.2010.10.012

Access to the published version may require journal subscription. Published with permission from: Elsevier.

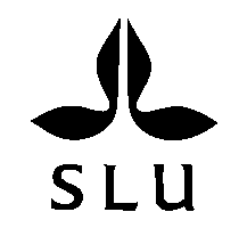

Epsilon Open Archive http://epsilon.slu.se 


\title{
Injection-molded nanocomposites and materials based on wheat gluten
}

\author{
S.-W. Cho ${ }^{1}$, M. Gällstedt ${ }^{2}$, E. Johansson ${ }^{3}$ and M. S. Hedenqvist ${ }^{1, *}$
}

${ }^{1}$ Fibre and Polymer Technology, Royal Institute of Technology, SE-100 44 Stockholm, Sweden

${ }^{2}$ Innventia, Box 5604, SE-114 86 Stockholm, Sweden

${ }^{3}$ Faculty of Landscape Planning, Horticulture and Agricultural Sciences, Swedish University of Agricultural Sciences, Box 104, SE-230 53 Alnarp, Sweden

* Corresponding author. Tel. +46-8-7907645; fax: +46-8-208856.E-mail address: mikaelhe@kth.se (M. S. Hedenqvist). 


\section{ABSTRACT}

This is, to our knowledge, the first study of the injection molding of materials where wheat gluten (WG) is the main component. In addition to a plasticizer (glycerol), 5 wt.\% natural montmorillonite clay was added. X-ray indicated intercalated clay and transmission electron microscopy indicated locally good clay platelet dispersion. Prior to feeding into the injection molder, the material was first compression molded into plates and pelletized. The filling of the circular mold via the central gate was characterized by a divergent flow yielding, in general, a stronger and stiffer material in the circumferential direction. It was observed that 20-30 wt.\% glycerol yielded the best combination of processability and mechanical properties. The clay yielded improved processability, plate homogeneity and tensile stiffness. IR spectroscopy and protein solubility indicated that the injection molding process yielded a highly aggregated structure. The overall conclusion was that injection molding is a very promising method for producing WG objects.

\section{Key words:}

Injection molding, nanocomposites, wheat gluten, montmorillonite, mechanical properties 


\section{Introduction}

Interest in renewable materials is increasing due to limited petroleum resources, increasing petroleum prices, environmental concerns and a general interest among companies to show a "green" profile. Several renewable and/or biodegradable materials have been developed and released onto the market within the last decade $[1,2]$. Others were available long before the petroleum-based plastics entered the market [2].

To be able to compete with conventional plastics, especially with respect to cost, it is of utmost importance that renewable plastics can be processed with the same methods as the former. This is a challenge, since several of these, including those based on proteins, are difficult to process. The "melt" viscosity of e.g. wheat gluten is high due to its high molar mass and aggregated structure. Nevertheless, it has been shown, by us and others, that plasticized wheat gluten can be compression molded and extruded into films, troughs and plates [3-8]. These methods, however, provide rather limited ways of shaping the material/product into more or less complicated three dimensional (3D) items. Injection molding, on the other hand, is a very versatile and commonly used method for producing 3D plastic goods. If the protein-based materials could be processed with this technique, it would open up the possibility of introducing a wide range of protein-based 3D goods onto the market. Examples of such products would be door-knobs, handles and covers/hoods for various in-door applications. Injection molding is, however, a harsh treatment for most thermoplastics [9], and several parameters have to be considered carefully in order to obtain optimal results, including dwell times, moisture content, processing temperatures, screw and injection speeds, cooling rates and times, mold design and surface finish, postmolding pressure and shrinkage [10-13]. 
The purpose of this project was to study whether it is possible to injection mold wheat gluten, and if so, to investigate the properties of the molded material. This is, to our knowledge, the first study on the injection molding of wheat gluten as the main component. Soy proteins have been studied for injection molding purposes with or without reinforcing fibers [14-16], corn gluten compounds [17], sun flower cake $[18,19]$ and sun flower protein isolate [20]. Several studies have also been reported on injection-molded starch-based compounds having a minor protein component, aimed for various food products [21] such as pasta [22] and pet food [23] and also including various meat proteins [24]. The studies of injection-molded proteins have included different kinds of additives [25], such as modified polyesters [26], compatibilizers and various plasticizers [27] or water [28], and/or reducing agents [27,29].

In addition to glycerol-plasticized vital wheat gluten, samples containing natural montmorillonite clays were injection molded and included in the investigation. The idea was to see whether these could be used to improve the processability and mechanical integrity/strength of the injection-molded article.

\section{Experimental}

\subsection{Materials}

The vital WG powder was kindly supplied by Reppe AB, Sweden. According to the supplier, the gluten protein content was $85.2 \%$ (according to Mod NMKL nr6, Kjeltec, Nx6,25), the starch content (according to Mod. NMKL Nr 6, Kjelldahl. Ewers.) was $5.84 \%$ (according Ewers, pol.), the concentration of fats (according to Soxtec, Lidfett.OA.19, tecator AN 301) was $1.2 \%$ and the ash content (according to NMKL 173 2nd ed) was $0.86 \%$. All these contents were based on the dry weight. The water content (according to NMKL 23 1991) was 6.9\% wt.\% per total weight. 
Glycerol, boiling point $\approx 290^{\circ} \mathrm{C}$, with a concentration of $\geq 99.5$ wt. $\%$ and a water content of $\leq 0.5$ wt.\% was supplied by Karlshamns Tefac AB, Sweden. Cloisite ${ }^{\circledR} \mathrm{Na}^{+}$ was a natural sodium-rich montmorillonite (MMT) obtained from Southern Clay Products Inc. (USA).

\subsection{Methods}

\subsubsection{Sample preparation}

Before injection molding, a dough was prepared with 20 or $30 \mathrm{wt} \%$ glycerol (samples IM-20 and IM-30) based on the total mass of the sample, or with 5 wt.\% of clay (Cloisite $\mathrm{Na}^{+}$, sample IM-Na) and $30 \mathrm{wt} . \%$ of glycerol (both amounts relative to the total amount of glycerol and gluten). The dough was compression molded at $110^{\circ} \mathrm{C}$ for 5 min under a set pressure of 200 bar into a ca $3 \mathrm{~mm}$ thick sheet and then pelletized by a cutter into cube-like particles. These pellets were used for injection molding using a Battenfeld BA500 CDK equipped with a three-zone-screw at Möllers Verktygsmakeri AB. The mold consisted of two stainless steel blocks. The diameter of the circular cavity in the ejector mold was $135 \mathrm{~mm}$ and the gate had a diameter of $4.5 \mathrm{~mm}$ and was located in the center of the circular mold cavity (Figure 1). After a trial optimization stage, involving temperature, pressure and time in both the injection and the clamping units, the following parameters were chosen; injection pressure: 400 bar for $2 \mathrm{~s}$, holding pressure (after/post pressure): 300 bar for $1.5 \mathrm{~s}$, injection volume: $34 \mathrm{~cm}^{3}$, mold temperature: $90^{\circ} \mathrm{C}$, cooling period: $30 \mathrm{~s}$. The temperature of the plasticating unit ("plasticating temperature") was varied between $140^{\circ} \mathrm{C}$ and $200^{\circ} \mathrm{C}$, depending on the material. The designations of the samples are given in Table 1 including the plasticating temperature. Figure 1 presents the directions and planes in the injection-molded circular samples used in this study. The samples were stored at 
$23^{\circ} \mathrm{C}$ and $50 \%$ relative humidity $(\mathrm{RH})$ for at least three days before any analysis. All surface-related characterizations, including X-ray diffraction (XRD) and infrared spectroscopy were conducted on the large sample surface facing the ejector mold.

\section{FIGURE 1}

In many cases the impact of glycerol and of clay on the properties of the molded sample was significantly greater than the effect of plasticating temperature. In these cases, for simplicity, the temperature was omitted from the sample designation, and a typical sample/sample data then represented all plasticating temperatures in the figures and sometimes also in the discussions. IM-20-160 and IM-30-140 were omitted from the figures and discussions because of their inferior processability and resulting poor homogeneity.

\subsubsection{Thickness measurements}

The thickness was measured using a Lorentzen \& Wettre Type 21 micrometer in accordance with SCAN-P 7:96 $6^{30}$ at $23{ }^{\circ} \mathrm{C}$ and $50 \% \mathrm{RH}$, at a static pressure of 100 $\mathrm{kPa}$. At least ten measurements were made on each sample.

\subsubsection{Tensile test}

A Zwick Z010 tensile tester equipped with a $500 \mathrm{~N}$ load cell and controlled by a testXpert 7.1 ${ }^{\circ}$ supplied by ZwickRoell and Lambda Instrument AB, respectively, was used to determine the tensile properties of the injection-molded gluten and nanocomposites at $23^{\circ} \mathrm{C}$ and $50 \% \mathrm{RH}$. The measurements were performed as described in ISO 527-3:1995(E) [31]. Dumb-bell shaped specimens, having a width of $4 \mathrm{~mm}$ in narrow section, were punched out from the samples and subsequently 
conditioned for three days in the same climate room before tensile testing. A crosshead speed of $100 \mathrm{~mm} / \mathrm{min}$ and an initial grip-to-grip distance of $40 \mathrm{~mm}$ were used. The strain was taken as the actual distance relative to the initial grip-to-grip distance and the stress was taken as the force divided by the cross-sectional area of the narrow section. The elastic (E-) modulus was estimated as the initial slope of the stress-strain curve. At least ten specimens from each sample were tested.

\subsubsection{Shrinkage measurement}

At least three specimens were cut from each sample with a diameter of 8 or 21 mm. The circumferential direction was indicated by an arrow using an indelible marker. The shrinkage measurement was carried out using a hot-plate, in which a cortical surface was covered with silicone oil to prevent the sample from sticking to it. The test specimens were put on the hot-plate and exposed to a temperature of $110 \pm$ $3^{\circ} \mathrm{C}$ for about $5 \mathrm{~h}$. The specimens were photographed in close-up mode, and the images were analyzed using the ImageJ $1.40 \mathrm{~g}$ software. Lengths, in both the circumferential and radial directions, were measured and the mean ratio was calculated for each specimen.

\subsubsection{X-ray diffraction (XRD)}

The X-ray diffractograms of the clay, the gluten-glycerol (30\%; IM-30) and the gluten-clay composites were obtained using an X'Pert Pro X-ray Diffraction System (PANalytical) with $\mathrm{CuK} \alpha$ radiation at $45 \mathrm{kV}$ and $35 \mathrm{~mA}$. An incident radiation wavelength, $\lambda$, of $1.54 \AA$ was used through the $5 \mathrm{~mm}$ long and $2 \mathrm{~mm}$ wide slit. The scanning speed and the step size were, respectively, $0.04^{\circ} / \mathrm{s}$ and $0.017^{\circ}$. The specimen rotation time was $60 \mathrm{rpm}$ and the scans were performed in the reflection mode from 1 to $40^{\circ}(2 \theta)$. 


\subsubsection{Transmission electron microscopy (TEM)}

The clay nanocomposite structure was studied by transmission electron microscopy using a Philips Tecnai 10 electron microscope. Samples were embedded in epoxy and cured overnight at $60^{\circ} \mathrm{C}$. Then, $\sim 50 \mathrm{~nm}$ thick sections were cut using an RMC ultramicrotome and placed onto Formvar/carbon-coated Cu-grids using a hairpin. The grids were transferred to the TEM and the sections were subsequently observed at $80 \mathrm{kV}$.

\subsubsection{Differential scanning calorimetry (DSC)}

The analysis was performed on a Mettler Toledo DSC 1, calibrated with an indium standard. Approximately $30 \mathrm{mg}$ of sample was placed in a $100 \mu \mathrm{L}$ aluminium pan having a pierced lid to admit the purge gas. The measurements were conducted in triplicate, and the average of the calculated parameters was taken as the representative value. The glass transition temperature $\left(T_{g}\right)$ was obtained as the average of three measurements performed with a nitrogen gas flow of $50 \mathrm{~mL} \mathrm{~min}{ }^{-1}$, with the following temperature program: $-80^{\circ} \mathrm{C}$ for $5 \mathrm{~min}$, heating to $170^{\circ} \mathrm{C}$ at a heating rate of $20^{\circ} \mathrm{C}$ $\min ^{-1}$, cooled to $-80^{\circ} \mathrm{C}$ at $20^{\circ} \mathrm{C} \min ^{-1},-80^{\circ} \mathrm{C}$ for $5 \mathrm{~min}$, and again heated to $170^{\circ} \mathrm{C}$ at $20^{\circ} \mathrm{C} \mathrm{min}^{-1}$. The glass transition temperature was calculated from the calorimetric data for the second heating cycle using the STAR ${ }^{\mathrm{e}}$ System software.

\subsubsection{Infrared spectroscopy (IR)}

Infrared spectra were obtained using a Perkin-Elmer Spectrum 2000 FTIR spectrometer, equipped with a MKII Golden Gate ${ }^{\mathrm{TM}}$ attenuated total reflection (ATR) device using a single reflection accessory fitted with a diamond crystal and controlled by the Spectrum program Version 3.02. Spectra were recorded on injection-molded 
sample surfaces that were pressed against the ATR-crystal. The spectra were taken as an average of 16 scans between $4000 \mathrm{~cm}^{-1}$ and $600 \mathrm{~cm}^{-1}$ at intervals of $1 \mathrm{~cm}^{-1}$ with a resolution of $4 \mathrm{~cm}^{-1}$.

\subsubsection{Protein solubility}

The amount and size distribution of proteins, extracted with sodium dodecyl sulfate (SDS) and sonication, of injection-molded samples were obtained using sizeexclusion high-performance liquid chromatography (SE-HPLC), together with a three-step extraction procedure according to Gällstedt et al. [34]. In the first extraction (ext 1), each sample was suspended in $1.5 \mathrm{~mL}$ of $0.5 \%$ SDS-phosphate buffer $(\mathrm{pH}$ 6.9) and vortexed for $10 \mathrm{~s}$. The suspension was then stirred for $5 \mathrm{~min}$ at $2000 \mathrm{rpm}$ and centrifuged for $30 \mathrm{~min}$ at $8160 \mathrm{~g}$ to obtain the supernatant protein. In the second extraction (ext 2), the pellet was re-suspended in the SDS buffer and sonicated with an ultrasonic disintegrator (Soniprep 150, Tamro) for $30 \mathrm{~s}$, amplitude 5, fitted with a 3 $\mathrm{mm}$ exponential microtip. The samples were then centrifuged (30 min, 8160g) to obtain a supernatant of proteins. In the third extraction (ext 3), the pellet was again resuspended in the SDS buffer and sonicated as above for $30+60+60 \mathrm{~s}$.

The extracts were filtered through $0.45 \mu \mathrm{m}$ filters (Millipore, Durapore Membrane Filters) before the SE-HPLC operation. SE-HPLC analyses were performed on a Waters HPLC system using a BIOSEP SEC-4000 Phenomenex column. Separation was achieved during 30 min by loading $20 \mu \mathrm{L}$ of sample into an eluant of $50 \%(\mathrm{v} / \mathrm{v})$ acetonitrile and water containing $0.1 \%(\mathrm{v} / \mathrm{v})$ trifluoroacetic acid at a flow rate of $0.2 \mathrm{~mL} \mathrm{~min}^{-1}$. Proteins were detected by UV absorption at $210 \mathrm{~nm}$. The amount of protein extracted after each extraction step was normalized with respect to the total protein solubility of an extruded WG/glycerol sample exposed to the three 
extraction steps [34]. The SE-HPLC chromatograms were divided into polymeric and monomeric fractions [35]. The polymeric proteins were referred to as those that were eluted before 17 min and consisted essentially of glutenin and albumin moieties, and the monomeric proteins, eluted later, consisted mainly of gliadins, albumins, globulins, peptides, and amino acids.

\subsubsection{Statistical analysis}

Statistical analyses were carried out with a statistical software program JMP version 5 (SAS Institute Inc). An analysis of variance (ANOVA) was carried out, followed by calculation of means for the different treatments with significances. A Student's t-test, which performs a statistical means comparison for each pair, was used at a significance level of 0.05 .

\section{Results and discussion}

\subsection{The injection molding process}

In order to determine the optimum temperature for the WG injection molding process, wheat gluten powder was fed alone into the plasticating unit of the injection molder (screw section) using a wide range of temperatures well above the protein denaturation temperature $\left(110\right.$ to $\left.200^{\circ} \mathrm{C}\right)$. It was found that the upper limit for native gluten powder was ca $140^{\circ} \mathrm{C}$. However the plasticated gluten was very brittle and foamy even below this temperature, and it was therefore plasticized with various amounts of glycerol and then processed. It is worth noting that the WG/glycerol dough with a glycerol concentration $\geq 35 \mathrm{wt} . \%$ was too sticky to be fed consecutively through the hopper, probably because of the use of a gravimetric feeder. A "loss-inweight" feeder would probably reduce this problem. For best sample quality and good repeatability, proper feeding is necessary. Consequently, it was decided that the 
WG/glycerol material was to be fed in pellet form; the pellets being produced from compression molded WG/glycerol sheets. One of the central elements in the injection molding process is the mold. The mold that had a gate at one end of the dumbbellshape cavity was not suitable, since the cavity was not filled properly due to the long distance the high viscous melt had to travel through a sprue and along the entire length of the dumbbell mold. The mold with a central gate directly connected to the plasticating unit (see the experimental section) was therefore used to achieve a more uniform material distribution.

After optimization of the process parameters (temperature, pressure and time) in both the injection and clamping units, the plasticized WG was successfully injectionmolded. The best results were obtained at $180-200^{\circ} \mathrm{C}$ for the $20 \mathrm{wt} . \%$ glycerol sample and $170-190^{\circ} \mathrm{C}$ for those containing $30 \mathrm{wt} . \%$ glycerol. Initially a wider range of glycerol contents was tested. It was observed, however, that 20-30 wt.\% plasticizer gave the best combination of good mechanical properties and good processability. It was also concluded that a glycerol content above 30 wt.\% was unnecessarily high; Gao et al. ${ }^{36}$ reported, for Kafirin-based films, that when the glycerol content was increased from 30 to 40 wt.\% a two phase system developed, as observed by DSC, implying that separate glycerol- and protein-rich components were formed.

In an attempt to further improve the mechanical/processing properties, injection molding (including the same type of pellet preparation as described above) was also conducted with the addition of clay. The choice of $5 \mathrm{wt} . \%$ clay was based on the work of Tunc et al. [37] who showed that this amount of MMT clay was sufficient to yield improved properties (thermal stability and water-vapor barrier) of cast WG-based films. Increasing the amount of clay did not lead to a further increase in e.g. thermal stability [37]. 
The color of the injection-molded samples depended on the actual thermal treatment and changed significantly above $160^{\circ} \mathrm{C}$ from brown to dark brown, probably because of more extensive Maillard reactions.

\subsection{Tensile properties}

The mechanical properties of the injection-molded sheets are shown in Table 1 . As expected, a higher glycerol content resulted in a lower E-modulus and lower tensile strength (compare samples IM-20 and IM-30 at similar processing temperature). The strain-at-break and tensile strength were inversely related. The strength was always greater in the circumferential direction than in the radial direction. It is proposed by Hochstetter et al. [38] that denatured protein molecules are oriented in the machine direction during extrusion. Since injection molding involves high shearing rates, it would be expected that molecular orientation occur also here. The addition of the clay led to similar or slightly higher tensile strength and similar or lower extensibility (strain-at-break) (compare IM-30 with IM-Na). The E-modulus of this material, processed at 180 and $190^{\circ} \mathrm{C}$, was higher in both the circumferential and radial directions by, respectively, factors of $\sim 1.7$ and $\sim 1.4$, relative to the samples without clay. To conclude, with regard to the mechanical properties, and within the limits of concentrations and temperature considered here, the glycerol content dominated over all other factors (plasticating temperature, addition of clay).

Besides the pasticisation power of glycerol itself it attracts water, also acting as a plasticiser. The water content in the samples $\left(180^{\circ} \mathrm{C}\right.$ plasticating temperature $)$ exposed to $23^{\circ} \mathrm{C}$ and $50 \% \mathrm{RH}$ was estimated by measuring the mass of the samples equilibrated at $23^{\circ} \mathrm{C} / 50 \% \mathrm{RH}$ and the mass of the samples after being stored for 1 week in a dessicator with silica gel. The following water contents (measured on six 
replicates) were obtained: $7.0 \pm 0.1$ (IM-20), 9.7 \pm 0.1 (IM-30) and 9.4 \pm 0.1 wt.\% (IM$\mathrm{Na}$ ). Hence the lower modulus and strength, and mostly higher extensibility, of the IM-30 and IM-Na samples, as compared to IM-20, were most likely a combination of both a higher glycerol content and a higher water content.

\section{TABLE 1}

\subsection{Orientation}

Figure 2 shows the ratio of the different mechanical properties in the circumferential and radial directions. Although the scatter was sometimes large, the data indicated a higher modulus and strength in the circumferential direction. The extensibility seemed to be highest in the circumferential direction for the samples without clay whereas the ratio was close to unity with the clay. These data suggest that the injection-molded samples were molecularly oriented preferably along the circumferential direction as a result of the divergent flow during the mold filling, an orientation process believed to occur in extrusion through the dissociation/unfolding and subsequent polymerization/crosslinking of protein chains [39].

\section{FIGURE 2}

As observed in Figure 2, again due to the divergent flow during mold filling, the higher stiffness and strength values in the circumferential direction were associated with a higher orientation (higher shrinkage ratio) in the same direction. However, there was no unique relationship between the various mechanical properties and the shrinkage ratio. The reason may partly have been that the dumbbell specimens, because of their length and the circular sample geometry, were not cut exactly parallel/perpendicular to the overall radial flow direction. 


\subsection{XRD and TEM}

Figure 3 shows the XRD patterns of the MMT clay, the WG/glycerol/MMT material, and a WG/glycerol sample without clay as a reference. The 001-basal spacing was for the clay $12.1 \AA$. In the injection-molded material, the d-001 spacing

increased to $17.3 \AA$, indicating that the clay tactoids were significantly swollen yielding, at least to some extent, an intercalated nanocomposite. Figure 4 show that the dispersion of the clay varied. Both well-separated clay platelets as well as denser clay structures (tactoids and intercalated structures) were observed. Thus, XRD and TEM together, indicated that intercalation was a dominating feature but that exfoliated structures were also present.

\section{FIGURES 3 and 4}

\subsection{DSC}

The glass transition was determined from the inflection point in the thermograms (Figure 5), the midpoint being considered to be $T_{g}$. The $T_{g}$ of the samples is given in Table 2. The higher glycerol content decreased the glass transition temperature by ca $10{ }^{\circ} \mathrm{C}$. In many cases, a higher plasticating temperature resulted in an increase in the $T_{g}$ because of a higher degree of crosslinking/polymerization of the WG proteins. $T_{g}$ was reduced slightly (but usually not significantly) when the clay was added to the WG/glycerol sample.

FIGURE 5, TABLE 2 


\subsection{Infrared spectroscopy}

The IR absorption in the amide I region is sensitive to changes in the protein secondary structures and is therefore suitable for the evaluation of their conformations [40]. The data manipulations were made with the Spectrum software. The infrared ATR absorbance spectra of the samples were Fourier self-deconvoluted with an enhancement factor, $\gamma$, of 2 and a smoothing filter of $70 \%$, and then baseline-corrected in the spectral range from 1700 to $1580 \mathrm{~cm}^{-1}$. Deconvolution was an interactive routine to find the most appropriate combination of parameters and they were here chosen, after several trials to achieve sufficient band-narrowing, to find the major components. According to literature, Fourier-deconvoluted amide I spectral shapes depend on a number of factors: e.g. plasticizer content, drying temperature [41], and sampling method (ATR or transmission) [42]. The amide I band positions and assignments, given in Table 3, were obtained from previously reported studies [41, 43-46]. The second derivative spectra obtained by the Savitzky-Golay function software were used to assign further band positions, since an objective procedure was more appropriate than deconvolution [47]. Finally, the Fourier-deconvoluted spectra were exported to Origin Pro 6.0 (Microcal Software Inc.) and the band curve fitting was carried out with multiple Gaussian peaks until the unconstrained fits reached a stable minimum $\left(\mathrm{R}^{2}\right.$ in all analyses $\left.>0.9997\right)$. The relative area of 9 peaks (components) was used to evaluate the secondary structure (Table 3).

\section{TABLE 3}


Water influences the protein structure and therefore also the amide I region [43]. Wellner et al. [47] stated that with increasing water content, hydrogen bonds in the hydrated solid protein were broken successively by water molecules, resulting in increasing extended, hydrated structures. The IR spectra in this study clearly showed that the injection molding process, as well as the plasticizer content, led to changes in the secondary structure of the constituent proteins. The band in the vicinity of 1650 $\mathrm{cm}^{-1}$ was the most predominant in the amide I region of the WG/glycerol dough (the spectrum is not shown), but it decreased in the injection-molded samples (Figure 6). Instead, the bands at $1618 \mathrm{~cm}^{-1}-1625 \mathrm{~cm}^{-1}$ were the strongest in all the injectionmolded samples (Figure 6), which indicated the presence of inter- and intra-molecular disulfide bonds stabilizing the high molecular weight protein fractions. The addition of clay seemed to slightly reduce these aggregation/polymerization tendencies.

\section{FIGURE 6}

\subsection{Protein solubility}

Gällstedt et al. [34] claimed that proteins from the unprocessed WG powder were difficult to dissolve using SDS and sonication, due to the aggregation in the native state. A third sonication step was therefore incorporated. The IM-30 samples generally showed greater solubilities than IM-20 after the first extraction, in which protein molecules were dissolved primarily by breaking secondary bonds (Table 4). After the sonication treatment, the total extractabilities of proteins in the IM-20 and IM-30 samples showed no significant difference, indicating no major differences in protein aggregation between the samples containing 20 or $30 \mathrm{wt} . \%$ of glycerol. The protein solubility of IM-Na was about $40 \%$ less than that of IM-30, and it became more difficult to dissolve protein by attempting to break both secondary bonds (SDS) and disulfide bonds (sonication). The material extracted from all the samples was 
principally protein monomers (MP) and the amount was generally relatively small (Table 4). The fact that no polymers were extracted, and also that the amount of monomers extracted was small, showed that the injection-molding operation yielded an extensive polymer network with large amounts of monomers incorporated. Interestingly, and in contrast to several other investigations carried out using compression-molded and extruded films [6,7], the lowest total solubility was obtained for the samples plasticated at the lowest temperatures. These results probably reflect the influence of a higher shear stress (high melt viscosity) at lower temperature and a corresponding higher protein aggregation.

\section{TABLE 4}

\section{Conclusions}

After optimization, the plasticating temperatures during injection molding were found to be preferably $180-200^{\circ} \mathrm{C}$ and $170-190{ }^{\circ} \mathrm{C}$ for the WG with, respectively, 20 and 30 wt.\% glycerol. The glycerol content seemed to have a greater effect on the mechanical properties than the other parameters studied (plasticating temperature and clay). The natural montmorillonite clay $\left(\right.$ Cloisite ${ }^{\circledR} \mathrm{Na}^{+}$) was found to have a lubricating effect and to facilitate the WG injection molding. At the same time it contributed somewhat to an increased stiffness and strength of the molded plates. In general, the stiffness and strength were higher in the circumferential direction than in the radial direction for all the samples, probably due to the divergent flow of the protein molecules during mold filling. IR spectroscopy showed that the injectionmolding process, as well as the presence of glycerol, changed the secondary structure of the proteins, but that the clay had a small effect. The overall conclusion was that injection molding was found to be a promising method for producing WG objects. 


\section{Acknowledgements}

Vinnova, the Swedish Governmental Agency for Innovation Systems (Project: 2004-01656 and 2006-02858), The Research Council Formas (Project: 2006-621) and the "Glupack" consortium are thanked for financial support. Maria Luisa Prieto-Linde is especially acknowledged for the HPLC analysis. 


\section{References}

[1] T. Deligio, Modern Plast. Worldwide 84 (2007) 50-51.

[2] R.A. Gross, B. Kalra, Science, 297 (2002) 803-807.

[3] A. Apichartsrangkoon, D.A. Ledward, A.E. Bell, J.G. Brennan, Food Chem. 63 (1998) 215-220.

[4] P.L. Weegels, R.J. Hamer, In Interaction: the keys to cereal quality; Hamer R. J., Hoseney R. C., Eds.; American Association of Cereal Chemists. MN, USA 95-123, 1998.

[5] A. Redl, M.H. Morel, J. Bonicel, S. Guilbert, B. Vergnes, Rheol. Acta, 38 (1999) 311-320.

[6] N.H. Ullsten, M. Gällstedt, E. Johansson, A. Gräslund, M.S. Hedenqvist, Biomacromolecules 7 (2006) 771-776.

[7] N.H. Ullsten; S.-W. Cho, G. Spencer, M. Gällstedt, E. Johansson, A. Gräslund, M.S. Hedenqvist, Biomacromolecules 10 (2009) 479-488.

[8] S.H. Wang, Edible thermoplastic and nutritious pet chew, Patent, US 6,455,083, 1999.

[9] S.I.S. Shaharuddin, M.S. Salit, E.S. Zainudin, Turkish J. Eng. Env. Sci. 30 (2006) 23-34.

[10] S.M.M. Yusoff, J.M. Rohani, W.H.W. Hamid, E. Ramly, Jurnal Teknologi, 41 (2004) 1-16.

[11] J. Nabialek, J. Koszkul, The influence of input data on the results of injection molding process simulation, In Proceeding of $13^{\text {th }}$ Int. Scientific Conference on achievements on mechanical and material engineering, 16-18 May, GliwiseWisla, Poland, AMME, 2005.

[12] C.-P. Fung, C.-H. Huang, J.-L. Doong, J. Reinf. Plast. Comp. 22 (2003) 51-66.

[13] C. Rauwendaal, Statistical Process Control in Injection Molding and Extrusion, Hanser Fachbuchverlag, Germany, 2008.

[14] A.K. Mohanty, P. Tummala, W. Liu, M. Misra, P.V. Mulukutla,. L.T. Drzal, J. Polym. Environm. 13 (2005) 279-285. 
[15] P. Tummala, W. Liu, L.T. Drzal, A.K. Mohanty, M. Misra, Ind. Eng. Chem. Res. 45 (2006) 7491-7496.

[16] H.C. Huang, T.C. Chang, J. Jane, J. Am. Oil Chem. Soc. 76 (1999) 11011108.

[17] S. Samarasinghe, A.J. Easteal, N.R. Edmonds, Polym. Int. 57 (2008) 359-364.

[18] A. Rouilly, O. Orliac, F. Silvestre, L. Rigal, Bioresour. Technol. 97 (2006) 553561.

[19] C. Doumeng, J. Leyris, A. Gaset, Method for making shaped objects from a vegetable raw material by injection-moulding, Patent, EP 0,988,948, 1999.

[20] O. Orliac, F. Silverstre, A. Rouilly, L. Rigal, Ind. Eng. Chem. Res. 42 (2003)1674-1680.

[21] J. Riedl, Raw material composition, in particular an injection-moulding compound, Patent, WO 94/14886, 1993.

[22] L. Panattoni, R.G. Odermatt, J.P. Halden, Injection moulded pasta dna process for making them, Patent, EP 1,036,508, 2000.

[23] L. Nie, M.D. Parker, K. Woo, C.C. Maningat, S.D. Bassi, Low calorie injection molded starch-based pet chew bodies, Patent, US 2006/0193959, 2006.

[24] E. Berger, E. Haussener, Method on making articles of edible or easily biodegradable material, Patent, US 5,378,418, 1995.

[25] Sumimoto Bakelite Co. Ltd. Improvements in and relating to edible thermoplastic moulding compositions containing starch and protein salts, Patent GB 1,532,783, 1975 .

[26] J. John, M. Bhatacharya, Polym. Int. 48 (1999) 1165-1172.

[27] S. Bassi, C.C. Maningat, R. Chinaswamy, L. Nie, Biodegradable, grain proteinbased solid articles and forming methods, Patent, WO 97/19988, 1997.

[28] J.-L. Jane, S. Wang, Soy protein-based thermoplastic composition for preparing molded articles, Patent, US 5,523,293, 1996.

[29] L. Lie, S.D. Bassi, M.D. Parker, Grain protein formulations that provide clean release from molding surfaces, and associated methods, patent, US 2008/0032033, 2008. 
[30] SCAN. Paper and Boards - Thickness and apparent sheet-density or apparent bulk-density. Serie: P. Designation: 7:96. Scandinavian Pulp, Paper and Board Testing Committee, Sweden, 1996.

[31] ISO 527-3:1995(E). Plastics - Determination of tensile properties. International Organization for Standardization, Geneva, 1995.

[32] P.D. Groot, L.J. Deck, Mod. Opt. 42 (1995) 389-401.

[33] T. Pettersson, A. Fogden, J. Imaging Sci. Techn. 50 (2006) 202-215.

[34] M. Gällstedt, A. Mattozzi, E. Johansson, M.S. Hedenqvist, Biomacromolecules 5 (2004) 2020-2028.

[35] E. Johansson, M. L. Prieto-Linde, J.Ö. Jönsson, Cereal Chem. 78 (2001) 19-25.

[36] C. Gao, M. Stading, N. Wellner, M.L. Parker, T.R. Noel, E.N.C. Mills, P.S. Belton, J. Agric. Food Chem. 54 (2006) 4611-4616.

[37] S. Tunc, H. Angellier, Y. Cahyana, P. Chalier, N. Gontard, E. Gastaldi, J. Membr. Sci. 289 (2007) 159-168.

[38] A. Hochstetter, R.A. Talja, H.J. Helén, L. Hyvonen, K. Jouppila, LWT, 39 (2006) 893-901.

[39] A. Redl, S. Guilbert, M.-H. Morel, J. Cereal Sci. 38 (2003) 105-114.

[40] F. Dousseau, M. Pézolet, Biochemistry, 29 (1990) 8771-8779.

[41] C. Mangavel, J. Barbot, Y. Popineau, J. Guéguen, J. Agric. Food Chem. 49 (2001) 867-872.

[42] M.V.D. Weert, P.I. Haris, W.E. Hennink, D.J.A. Crommelin, Anal. Biochem. 297 (2001) 160-169.

[43] D.M.R. Georget, P.S. Belton, Biomacromolecules 7 (2006) 469-475.

[44] S.P. Makarenko, V.A. Trufanow, T.E. Putilina, Russ. J. Plant Physiol. 49 (2002) 365-370.

[45] N. Wellner, E.N.C.; Mills, G. Brownsey, R.H. Wilson, N. Brown, J. Freeman, N. G. Halford, P.R Shewry, P.S. Belton, Biomacromolecules 5 (2005) 255-261.

[46] J.T. Pelton, L.R. McLean, Anal. Biochem. 277 (2000) 167-176.

[47] N. Wellner, P.S. Belton, A.S. Tatham, Biochem. J. 319 (1996) 741-747. 
Table 1. Mechanical properties of the injection-molded plates in the circumferential (CD) and radial (RD) directions.

\begin{tabular}{|c|c|c|c|}
\hline Sample $^{1}$ & E-modulus (MPa) & Max stress $(\mathrm{MPa})$ & Strain at break $(\%)$ \\
\hline \multicolumn{4}{|l|}{$\mathrm{CD}$} \\
\hline IM-20-160 & $139 \pm 25 \mathrm{c}$ & $4.7 \pm 0.8 \mathrm{c}$ & $6.6 \pm 2.9 \mathrm{de}$ \\
\hline IM-20-180 & $147 \pm 28 \mathrm{c}$ & $5.5 \pm 1.1 b$ & $9.1 \pm 4.1 \mathrm{~d}$ \\
\hline IM-20-190 & $234 \pm 36 a$ & $6.2 \pm 1.7 \mathrm{ab}$ & $4.2 \pm 2.1 \mathrm{e}$ \\
\hline IM-20-200 & $217 \pm 30 b$ & $6.6 \pm 1.9 \mathrm{a}$ & $6.9 \pm 3.2 \mathrm{de}$ \\
\hline IM-30-140 & $26 \pm 3$ & $1.6 \pm 0.2 \mathrm{e}$ & $16.3 \pm 5.0 \mathrm{c}$ \\
\hline IM-30-170 & $21 \pm 5$ & $1.5 \pm 0.3 \mathrm{e}$ & $21.2 \pm 9.6 \mathrm{~b}$ \\
\hline IM-30-180 & $28 \pm 2$ & $1.9 \pm 0.3 \mathrm{de}$ & $14.7 \pm 4.3 \mathrm{c}$ \\
\hline IM-30-190 & $19 \pm 6 \quad \mathrm{e}$ & $1.3 \pm 0.3 \mathrm{e}$ & $18.5 \pm 7.0 \mathrm{bc}$ \\
\hline IM-Na-180 & $44 \pm 6$ & $1.9 \pm 0.3 \mathrm{de}$ & $6.3 \pm 1.9 \mathrm{de}$ \\
\hline IM-Na-190 & $33 \pm 5$ & $2.4 \pm 0.5 \mathrm{~d}$ & $18.0 \pm 6.9 \mathrm{bc}$ \\
\hline IM-Na-200 & $32 \pm 3 \mathrm{de}$ & $2.5 \pm 0.4 \mathrm{~d}$ & $26.6 \pm 7.4 \mathrm{a}$ \\
\hline \multicolumn{4}{|l|}{$\mathrm{RD}$} \\
\hline IM-20-160 & $110 \pm 15 b$ & $4.0 \pm 0.9 b$ & $5.6 \pm 1.8$ ef \\
\hline IM-20-180 & $119 \pm 20 b$ & $4.1 \pm 0.8 b$ & $6.6 \pm 2.6 \mathrm{ef}$ \\
\hline IM-20-190 & $186 \pm 38 \mathrm{a}$ & $4.4 \pm 1.2 b$ & $3.6 \pm 1.7 \mathrm{f}$ \\
\hline IM-20-200 & $182 \pm 21 \mathrm{a}$ & $5.5 \pm 0.8 \mathrm{a}$ & $5.9 \pm 1.9$ ef \\
\hline IM-30-140 & $19 \pm 3 d$ & $1.0 \pm 0.2 \mathrm{e}$ & $12.2 \pm 5.0 \mathrm{~d}$ \\
\hline IM-30-170 & $16 \pm 6$ & $1.1 \pm 0.1 \mathrm{e}$ & $18.2 \pm 7.3 \mathrm{~b}$ \\
\hline IM-30-180 & $22 \pm 3$ & $1.4 \pm 0.2 \mathrm{cde}$ & $16.0 \pm 2.8 \mathrm{bc}$ \\
\hline IM-30-190 & $19 \pm 5$ & $1.2 \pm 0.2 \mathrm{de}$ & $16.7 \pm 7.3 \mathrm{bc}$ \\
\hline IM-Na-180 & $32 \pm 3$ & $1.4 \pm 0.3 \mathrm{cde}$ & $7.5 \pm 2.2 \mathrm{e}$ \\
\hline IM-Na-190 & $27 \pm 3$ & $1.7 \pm 0.2 \mathrm{~cd}$ & $14.4 \pm 3.7 \mathrm{~cd}$ \\
\hline IM-Na-200 & $27 \pm 3 \quad \mathrm{~cd}$ & $1.9 \pm 0.3 \mathrm{c}$ & $25.2 \pm 3.4 \mathrm{a}$ \\
\hline
\end{tabular}

Mechanical properties are given with the average value, standard deviation and significance difference (Levels having the same letter are not significantly different.). The $\mathrm{CD}$ and $\mathrm{RD}$ data have been considered separately in the statistics.

${ }^{1}$ Samples are designated as follows: The first part abbreviates injection-molded gluten/ nanocomposites, the second part represent different compositions, and the third part shows the processing temperatures in the plasticating unit of injection molder, respectively. 
Table 2. Glass transition temperatures of the injection-molded plates, determined by DSC.

\begin{tabular}{|c|c|c|}
\hline Sample & \multicolumn{2}{|c|}{$T_{\mathrm{g}}\left({ }^{\circ} \mathrm{C}\right)$} \\
\hline IM-20-160 & $40.8(3.4)$ & $\mathrm{c}$ \\
\hline IM-20-180 & $42.5(0.7)$ & $\mathrm{bc}$ \\
\hline IM-20-190 & $45.7(2.3)$ & $\mathrm{a}$ \\
\hline IM-20-200 & $44.6(0.6)$ & $a b$ \\
\hline IM-30-140 & $33.9(1.4)$ & de \\
\hline IM-30-170 & $31.4(1.2)$ & efg \\
\hline IM-30-180 & $33.1(2.2)$ & def \\
\hline IM-30-190 & $35.7(1.3)$ & $\mathrm{d}$ \\
\hline IM-Na-180 & $31.6(0.5)$ & efg \\
\hline IM-Na-190 & $29.8(2.4)$ & $\mathrm{g}$ \\
\hline IM-Na-200 & $30.1(1.7)$ & $\mathrm{fg}$ \\
\hline
\end{tabular}

The values in parentheses are standard deviations.

*Levels having the same letter are not significantly different. 
Table 3. Characterization of the deconvoluted IR spectra: Relative contents of the secondary structure in the Amide I region. The injection-molded plates were plasticated at $180^{\circ} \mathrm{C}$.

\begin{tabular}{|c|c|c|c|c|}
\hline \multicolumn{2}{|r|}{ Secondary structure } & \multicolumn{3}{|c|}{ Relative area of Gaussian components $(\%)$} \\
\hline $\begin{array}{c}\text { Position } \\
\left(\mathrm{cm}^{-1}\right)\end{array}$ & Assignment & IM-20 & IM-30 & $\mathrm{IM}-\mathrm{Na}$ \\
\hline 1691 & $\beta$-turns & 2.3 & 2.3 & 2.5 \\
\hline 1680 & $\begin{array}{c}\beta \text {-sheets, weakly hydrogen- } \\
\text { bonded peptide groups }\end{array}$ & 4.1 & 4.2 & 4.1 \\
\hline 1667 & $\beta$-turns & 20.2 & 22.3 & 22.8 \\
\hline 1658 & $\alpha$-helices & 4.1 & 3.9 & 3.3 \\
\hline 1651 & $\alpha$-helices and random coils & 9.1 & 8.3 & 8.9 \\
\hline 1644 & unordered & 8.0 & 8.9 & 7.9 \\
\hline 1634 & $\begin{array}{l}\beta \text {-sheets, weakly hydrogen- } \\
\text { bonded peptide groups }\end{array}$ & 9.7 & 7.9 & 10.8 \\
\hline 1625 & $\begin{array}{l}\beta \text {-sheets, strongly hydrogen- } \\
\text { bonded peptide groups }\end{array}$ & 8.7 & 4.5 & 4.7 \\
\hline 1618 & $\begin{array}{l}\beta \text {-sheets, strongly hydrogen- } \\
\text { bonded peptide groups }\end{array}$ & 33.8 & 37.7 & 34.9 \\
\hline
\end{tabular}


Table 4. Protein solubility ${ }^{1}$

\begin{tabular}{lrrrrr}
\hline \multicolumn{1}{c}{ Treatment } & ext1 & ext2 & ext3 & Total & PP/MP \\
\hline Control & 30.2 & 29.3 & 40.5 & 100.0 & 0.77 \\
IM-20-160 & 5.8 & 6.2 & 4.5 & 16.5 & 0.09 \\
IM-20-180 & 28.9 & 36.5 & 25.2 & 90.6 & 0.05 \\
IM-20-190 & 23.4 & 29.9 & 24.0 & 77.3 & 0.04 \\
IM-20-200 & 19.1 & 25.0 & 21.8 & 65.9 & 0.07 \\
IM-30-140 & 4.8 & 5.6 & 5.0 & 15.5 & 0.12 \\
IM-30-170 & 48.3 & 25.3 & 25.1 & 98.7 & 0.06 \\
IM-30-180 & 41.2 & 21.5 & 20.4 & 83.1 & 0.05 \\
IM-30-190 & 42.2 & 22.4 & 21.2 & 85.8 & 0.05 \\
IM-Na-180 & 25.1 & 14.4 & 14.9 & 54.4 & 0.06 \\
IM-Na-190 & 32.4 & 17.7 & 18.7 & 68.8 & 0.06 \\
IM-Na-200 & 25.1 & 15.1 & 15.2 & 55.4 & 0.05 \\
\hline
\end{tabular}

${ }^{1}$ All values were normalized to the total solubility (Total=ext $\left.1+\operatorname{ext} 2+\operatorname{ext} 3\right)$ of an extruded wheat gluten $/ 30 \%$ glycerol sample described in Ref 30 .

${ }^{2} \mathrm{PP}$, "Polymeric" proteins; MP, "Monomeric" proteins. 


\section{LEGENDS TO FIGURES}

Fig. 1. The directions in the injection-molded plate.

Fig. 2. The ratio of the circumferential direction (CD) to the radial direction (RD) for the mechanical properties and shrinkage (the test specimens plasticated at $\left.180^{\circ} \mathrm{C}\right)$.

Fig. 3. XRD patterns of the clay $\left(\right.$ Cloisite $^{-} \mathrm{Na}^{+}$), WG (glycerol plate with $30 \%$ glycerol (IM-30) and the WG/glycerol/clay (IM-Na) composite. The injectionmolded plates were plasticated at $180^{\circ} \mathrm{C}$. Arrows indicate the positions of the d001 reflection.

Fig. 4. Transmission electron micrograph of the an IM-Na sample.

Fig. 5. DSC thermograms taken during the second heating.

Fig. 6. IR spectra (left) and Fourier-deconvoluted infrared spectra (ATR) of amide I band fitted with a sum of Gaussian bands: (A) IM-20, (B) IM-30 and (C) IM$\mathrm{Na}$ (plasticated at $\left.180^{\circ} \mathrm{C}\right)$. 

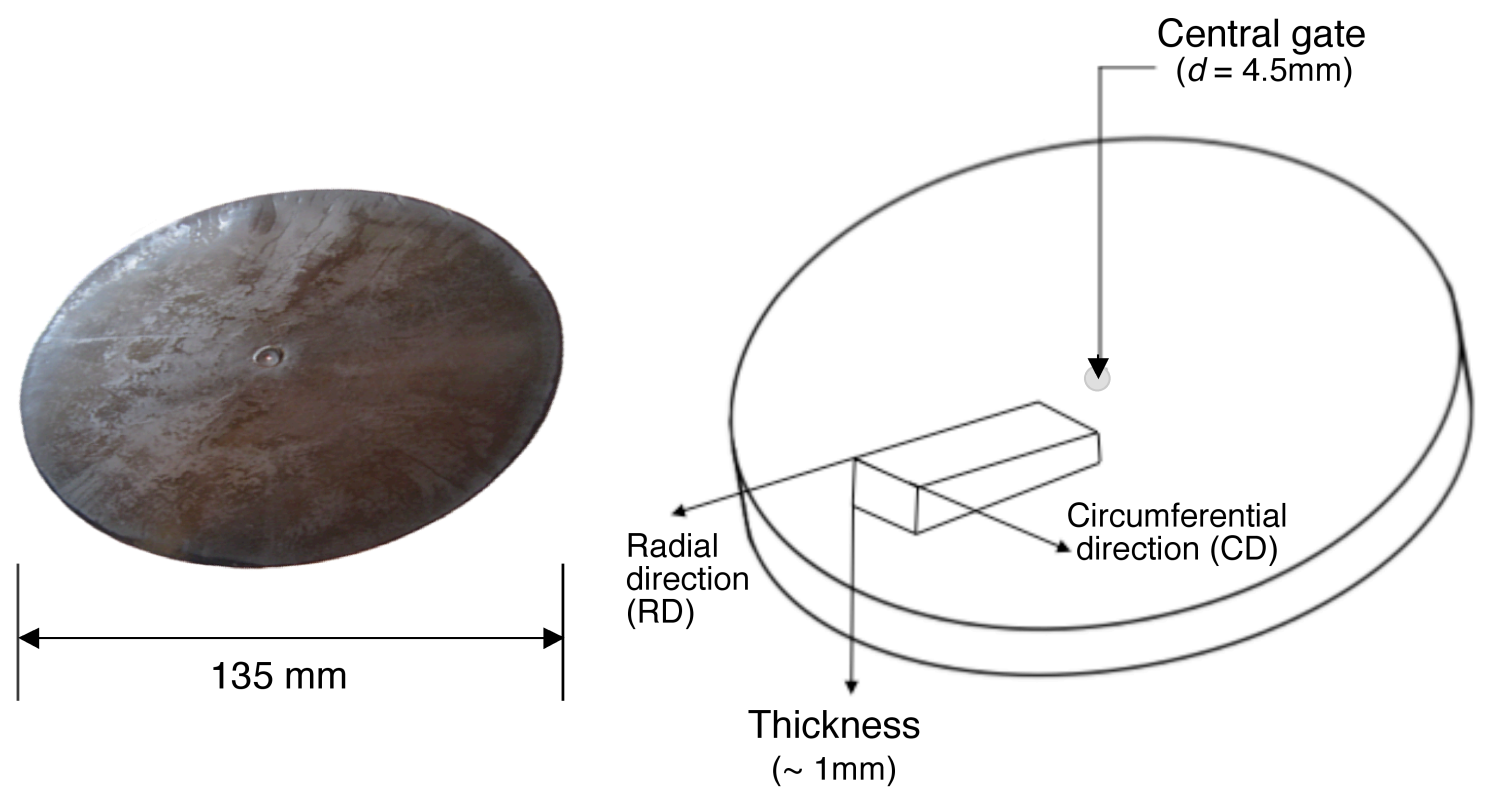

Figure 1. Cho et al._nternational journal of Biological Macromolecules 


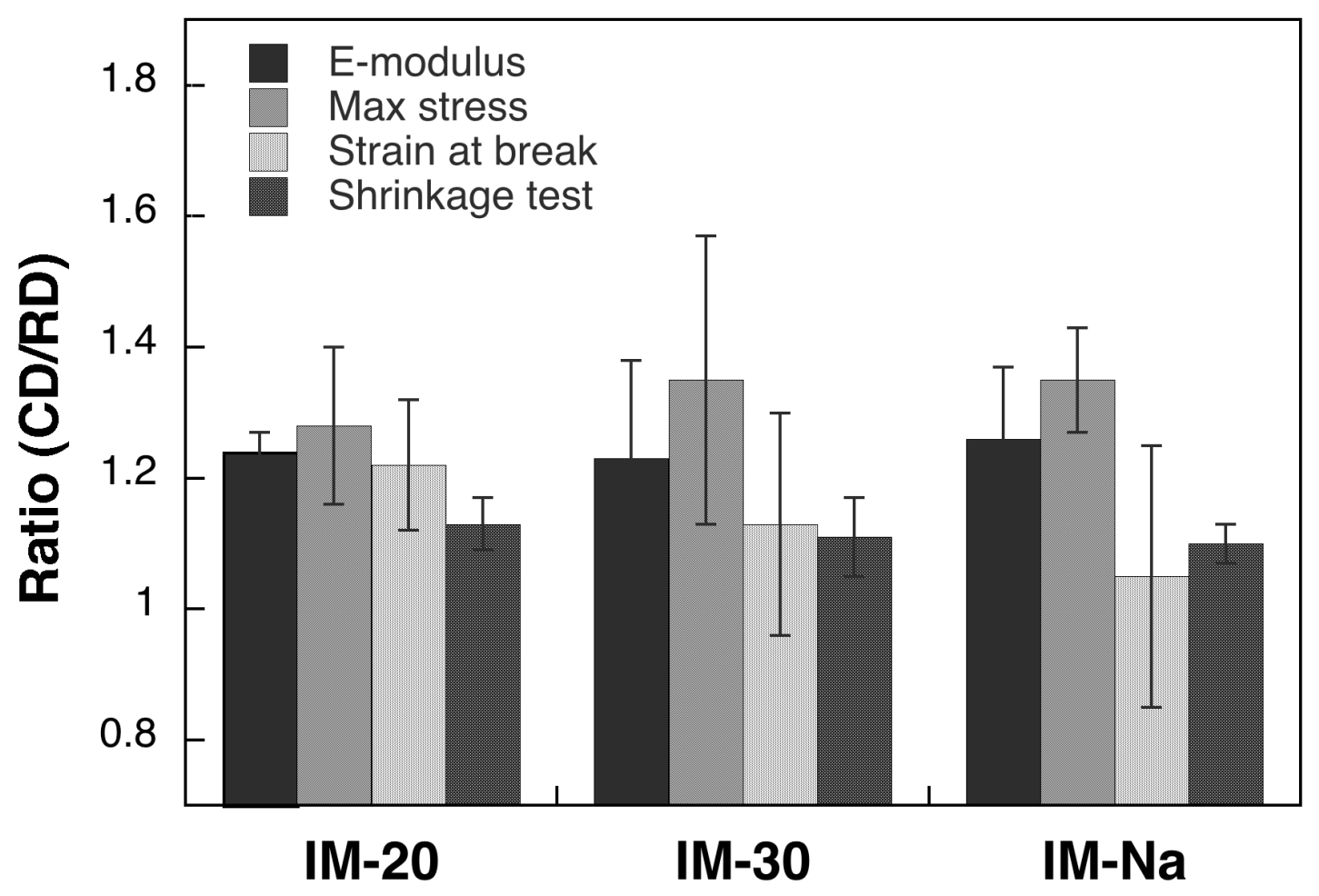

Figure 2. Cho et al. International journal of Biological Macromolecules 


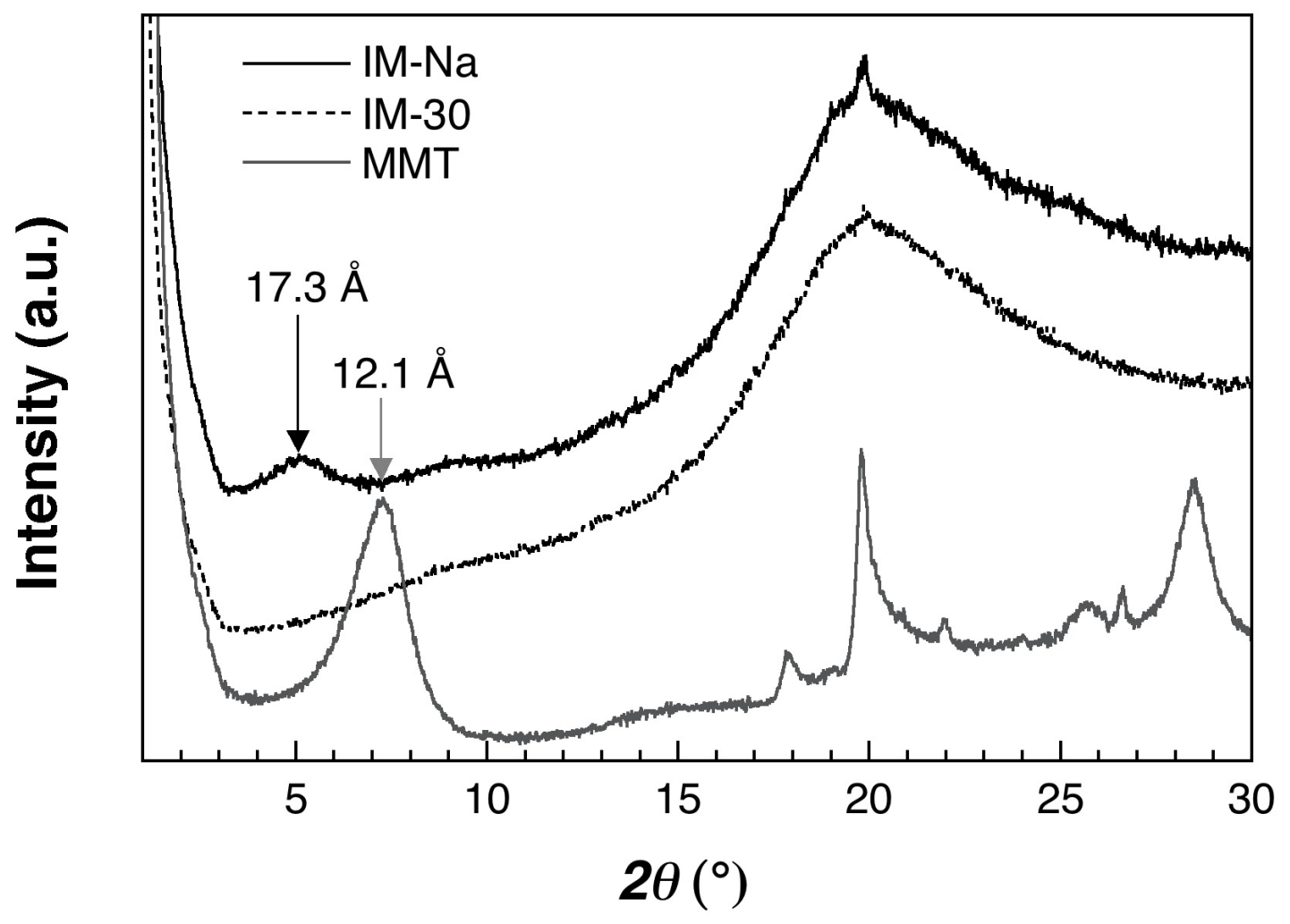

Figure 3. Cho et al. International journal of Biological Macromolecules 


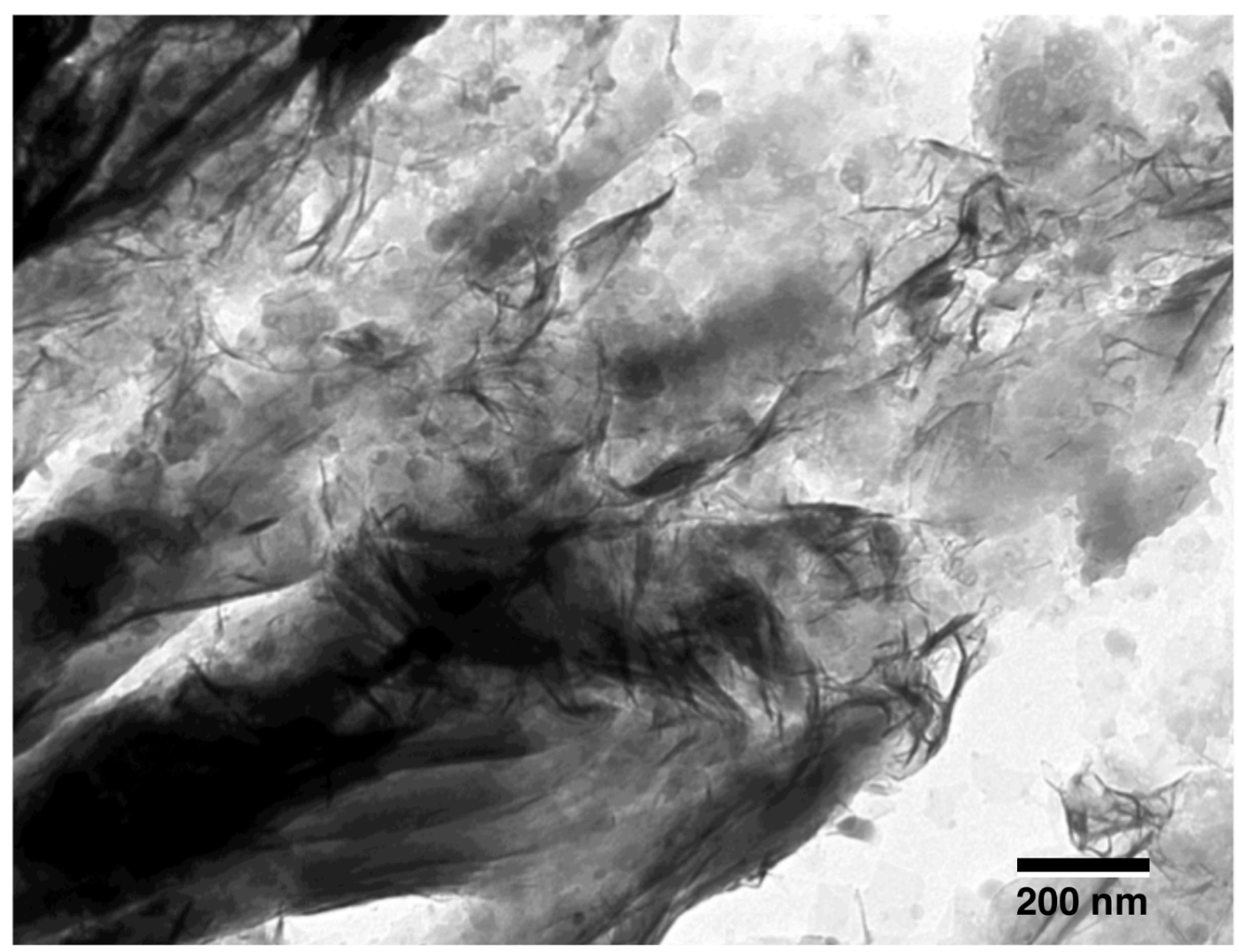

Figure 4. Cho et al. International journal of Biological Macromolecules 


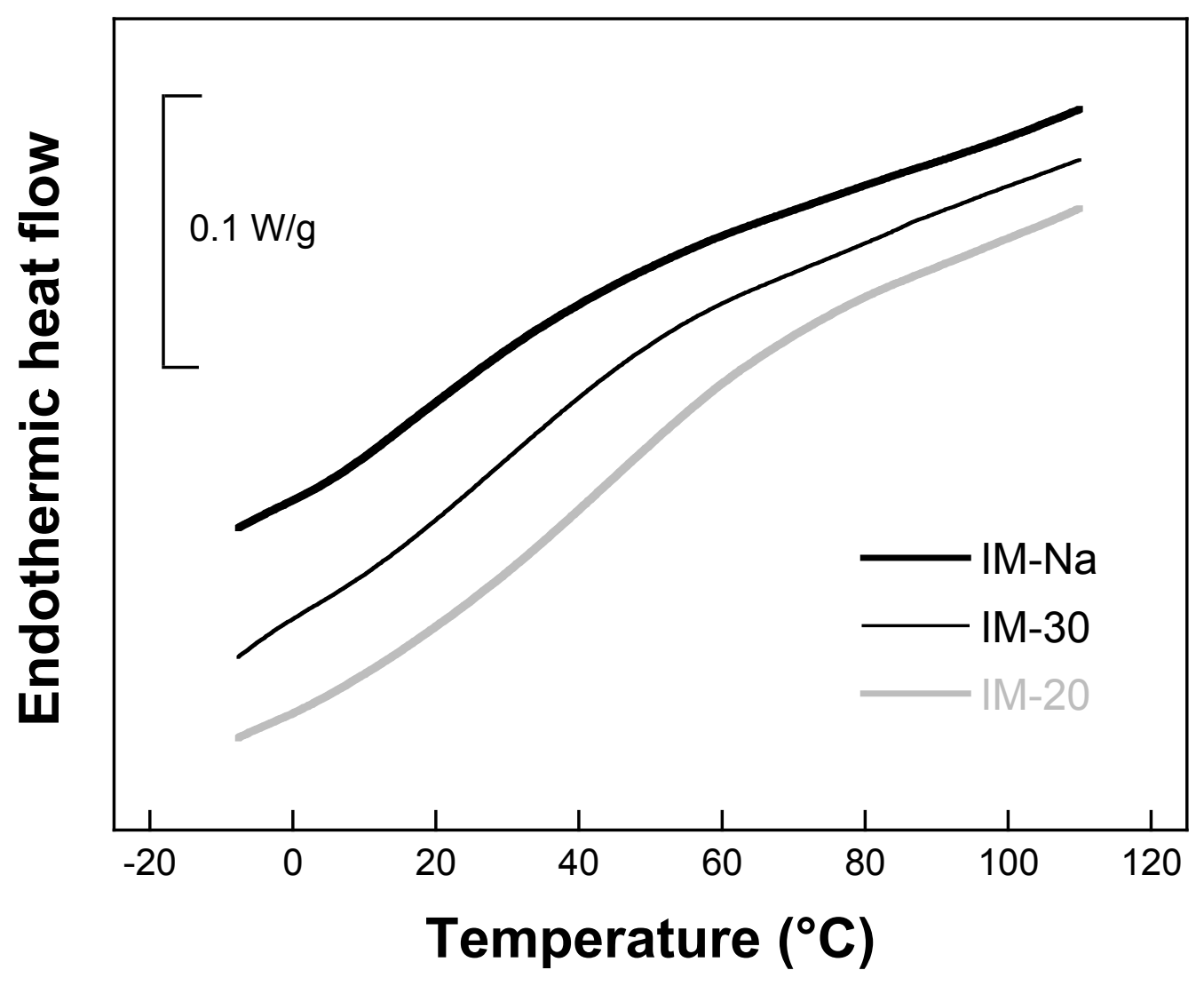

Figure 5. Cho et al. International journal of Biological Macromolecule 


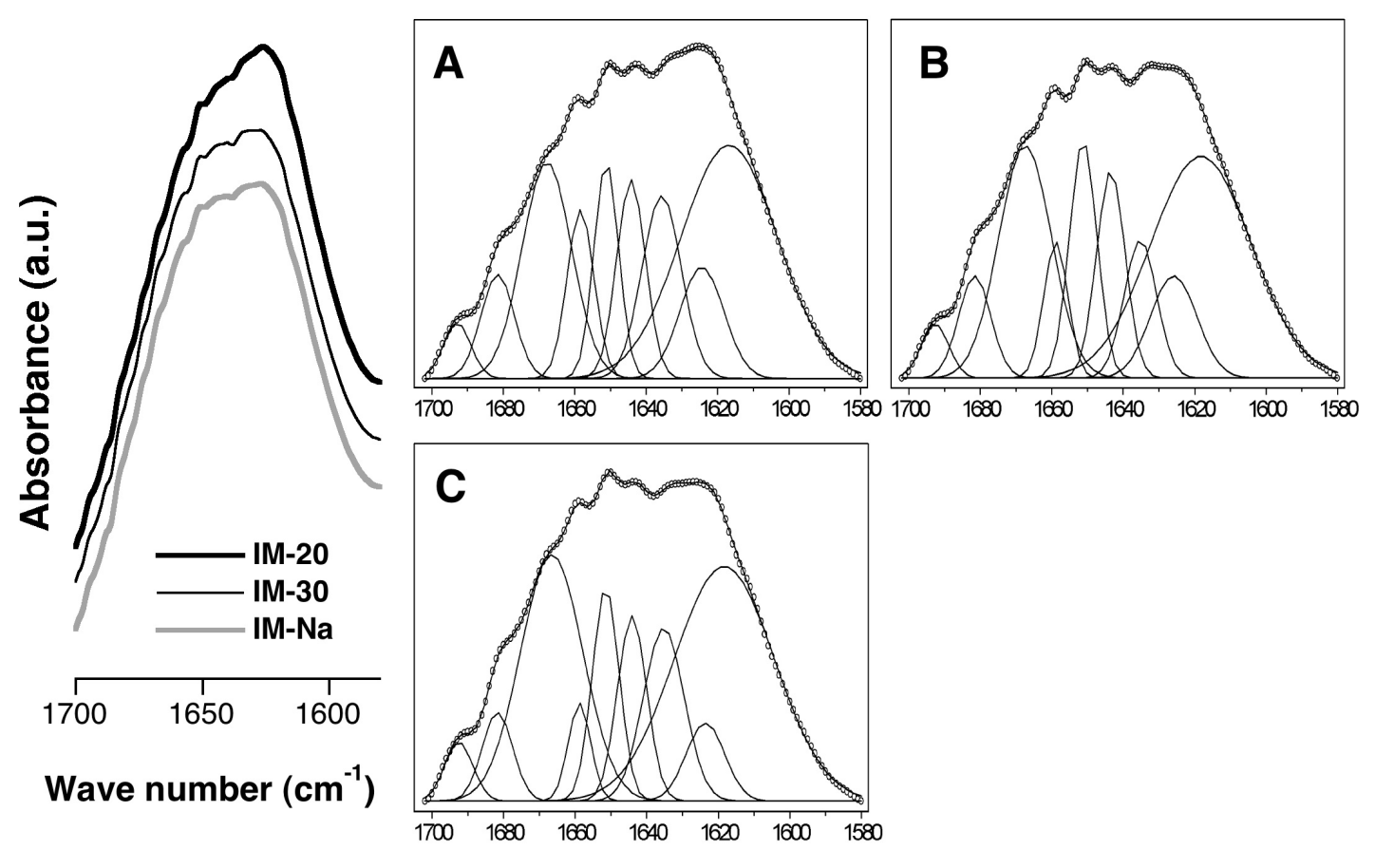

Figure 6. Cho et al. International journal of Biological Macromolecules 